\title{
DISKRESI HAKIM DALAM MENETAPKAN HUKUM DI PENGADILAN AGAMA KELAS IB BATUSANGKAR
}

\author{
Sri Yunarti \\ Program Pascasarjana UIN Sunan Gunung Djati Bandung \\ Jl. Cimencrang Samping Polda Jabar Bandung \\ e-mail: sriyunarti@gmail.com
}

\begin{abstract}
So far the verdict courts made by Pengadilan Agama (PA/ Family Court) have been criticized for being too fixated on legal justice approaches and lack of attention to social justice approaches. This criticism demands that judge's understanding of the law holds to the spirit that underlies the formation of the law. The judge needs to use his or her authority to exercise legal discretion, using more moral rather than formal legal ideas. A judge must understand the law in the right contest and act as a creative lanyer. Discretion is the authority of the judge to decide cases with more consideration of the sense of justice, public interest and morality, which develops in society rather than deciding on the basis of the decisions of the regulations contained in the Law. This authority can be used an alternative in response to the absence and weaknesses in the application of legal principles in Civil Law System. Thus the law is expected to play a maximum role to serve the interests of the dynamic community put the interests of both parties who are in dispute and growing as well.
\end{abstract}

Kata kunci: diskresi hakim, Pengadilan Agama

\section{PENDAHULUAN}

P engadilan Agama merupakan salah satu lembaga peradilan di Indonesia yang berwenang menerima, memeriksa dan memutuskan serta menyelesaikan perkara perdata antara orang-orang yang beragama Islam yang meliputi perkara perkawinan, kewarisan, wasiat, hibah, wakaf, zakat, infaq dan sadaqah, dan ekonomi syari'ah, sesuai dengan pasal 49 UU No. 7 Tahun 1989 yang telah diubah UU No. 3 Tahun 2006,UU No. 50 Tahun 2009 tentang perubahan kedua atas Undang-undang No. 7 Tahun 1989 Tentang Peradilan Agama dengan kompetensi Relatif wilayah Sumatera Barat. Pasal 9 ayat 1 Undang-Undang No. 7 Tahun 1989 jo Undang-Undang No. 3
Tahun 2006 jo Undang-Undang No. 50 Tahun 2009, menyatakan bahwa Pengadilan Agama adalah Pengadilan bagi orang-orang yang beragama Islam (Daud Ali, 2001: 325). Jadi, pengadilan Agama hanya berwenang memeriksa, mengadili, dan memutuskan perkaraperkara tertentu pada tingkat pertama (Yahya Harahab, 2001: 9).

Fenomena hakim di Pengadilan Agama dalam memutus suatu perkara telah ditempuh pada pendekatan legal Justice dan kurang memperhatikan pendekatan social justice yang terpaku pada teks hukum, sehingga hakim lebih mengedepankan asas kepastian hukum dari pada kewajiban untuk menegakkan keadilan. Cara pandang yang membakukan 
teks hukum ini menurut Satjipto Raharjo, akan berimplikasi pada bentuk kegagalan dan terjadinya bentuk pemandulan dari fungsi hukum itu sendiri, kotroversi inilah yang diletakkan pada keputusan yang ditetapkan oleh hakim yang dianggap telah keluar dari apa yang ditentukan oleh Undang-undang. Pengadilan dihadapkan pada rasa keadilan masyarakat (kebenaran materiil), namun Reichel telah memberikan sinyal bagi para penegak hukum dengan berpendapat "hakim berkewajiban untuk dengan sengaja menyimpang dari suatu peraturan hukum apabila peraturan itu bertentangan dengan perasaan moral masyarakat" (Lili Rasjidi, 2001: 79).

Dalam wacana hukum Islam dikenal dengan adanya istilah ijtihad, sebagai aktifitas penggalian hukum Islam, dalam menjawab problematika hukum Islam yang terjadi di tengah-tengah masyarakat. Beberapa metode ijtihad dimungkinkan terdapat kasus-kasus yang diputuskan dengan diskresi. Hal ini menjadi indikasi bahwa para pelaku ijtihad tidak terpaku begitu saja pada ayat Alquran dan Hadis secara literalis. Tetapi mereka juga mempertimbangkan asas-asas, maksud dan tujuan dibalik teks nash tersebut. Sehingga ketika menetapkan suatu hukum boleh jadi mereka "keluar" dari ketentuan eksplisit Alquran dan Hadis, meskipun tetap berlandaskan pada tujuan penetapan hukum atau maqasid al-shari'ah yang meliputi memelihara agama, jiwa, harta, kehormatan dan keturunan.

Pelaksanaan putusan (eksekusi) sering kali menemui kendala bahkan sulit untuk dilaksanakan secara riil, baik oleh para pihak secara kekeluargaan maupun oleh jurusita saat di perintahkan untuk di lakukan eksekusi oleh Ketua Pengadilan
Agama, di mana kasus yang sering terjadi menyangkut tentang harta bersama, fasakh nikah, isbath nikah ataupun pelaksanaan nafkah anak, hak-hak istri (nafkah iddah dan mut'ah) (IKAHI, 2010 : 77) yang dirumuskan dalam hukum seringkali begitu kabur, sehingga hakim harus menafsirkan dalam kontek yang ia hadapi. Dalam konteks yang lebih spesifik, hakim yang biasanya dihadapkan pada perkara yang terkadang apabila didasarkan pada normatif Hukum, sangat terkesan menimbulkan ketidakadilan Hukum. Sehingga dibutuhkan diskresi Hakim dalam hal-hal tertentu yang memang tidak bisa dihindari dan sangat sulit sifatnya, baik dalam konteks hukum perkawinan maupun kewarisan.

Dengan demikian metode penemuan hukum melalui diskresi merupakan salah satu daya tarik bagi penulis untuk menelusuri lebih lanjut alternatif untuk mengatasi kemandulan hukum di Indonesia, terutama mengatasi ketidakmampuan melayani kepentingan Untuk menjadi ujung tombak penegakan hukum agar dapat mewujudkan hukum yang progresif, maka para penegak hukum harus bertindak sebagai a cretive lawyer.

\section{METODE PENELITIAN}

\section{Jenis Penelitian}

Adapun jenis penelitian yang dipakai dalam penelitian ini adalah penelitian lapangan (field research), yaitu penelitian lapangan yang dilakukan di Pengadilan Agama Tingkat pertama Kelas IB di Batusangkar.

Untuk menjawab permasalahan yang telah dirumuskan dalam penelitian ini, digunakan dua jenis penelitian, yaitu 


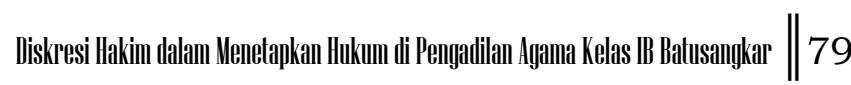

penelitian hukum normatif (yuridis Normatif) dan penelitian empiris (yuridis empiris).

Penelitian Hukum Normatif (yuridis normatif) adalah metode penelitian hukum yang dilakukan dengan meneliti bahan pustaka atau data sekunder belaka (Soerjono Soekanto, 2001 : 13-14). Dalam kaitannya dengan penelitian normatif di sini akan digunakan beberapa pendekatan, yaitu :

1. Pendekatan perundang-undangan (statute approach).

2. Pendekatan konsep (conceptual approach).

\section{Sumber Data}

Adapun sumber data yang penulis gunakan dalam penelitian ini adalah:

1. Sumber data primer, Majelis Hakim pada Pengadilan Agama Tingkat pertama kelas IB Batusangkar yang menyelesaikan perkara Permohonan tentang harta bersama, Fasakh Perkawinan, Dispensasi Nikah.

2. Sumber data sekunder, yaitu sumber data tambahan yang di peroleh dari buku-buku yang terkait dengan masalah serta karya ilmiah lainya yang berhubungan dengan perkara yang diteliti.

Berdasarkan hasil observasi dan wawancara serta dokumen yang penulis di lapangan, terdapat suatu kasus yang tidak sesuai dengan Undang-Undang dan ketentuan hukum dalam memutuskan perkara yang terdapat di Pengadilan Agama Tingkat pertama Kelas IB

\section{Teknik Analisis Data}

Setelah data terkumpul melalui teknik pengumpulan data, langkah selanjutnya adalah diolah dan dianalisis data tersebut dengan memberikan penafsiran dan langkah-langkah membuat kategori untuk menglkasifikasi jawaban sebagai kerangka analisa data yang diperoleh dengan menggunakan metode deskriptif kualitatif, yaitu suatu metode yang berusaha mendeskripsikan suatu gejala, peristiwa atau kejadian sosial yang terjadi pada saat sekarang yang berhubungan dengan tema atau obyek penelitian. Studi kasus merupakan penelitian tentang status subjek penelitian yang berkenaan dengan fase spesifik atau khas dari keseluruhan personalita.

Dalam penelitian ini, data yang terkumpul berbentuk kata-kata, dan bukan angka. Kalaupun ada angka-angka, sifatnya hanya sebagai penunjang. Data yang diperoleh meliputi transkip, interview, catatan lapangan dan lain-lain.

Dari uraian di atas dapat disimpulkan bahwa dalam penelitian ini, peneliti menggunakan metode observatif kualitatif, di mana setelah memperoleh data dari hasil pengamatan dan wawancara, peneliti kemudian menyusun data tersebut, menjelaskan dan dilanjutkan dengan menganalisis data tersebut.

Adapun langkah-langkahnya sebagai berikut:

1. Menelaah data yang diperoleh dari informan dan literatur terkait.

2. Mengklasifikasikan data dan menyusun berdasarkan kategorikategori.

3. Setelah data tersusun data terklasifikasi kemudian langkah selanjutnya adalah kesimpulan atau penarikan kesimpulan berdasarkan data yang ada.

Data yang diperoleh baik dari penelitian lapangan akan dianalisis secara 
deskriptif analisis, yaitu penelitian yang berusaha mendeskripsikan suatu gejala, peristiwa, dan kejadian yang terjadi saat sekarang. Penelitian deskriptif memusatkan perhatian kepada masalahmasalah aktual sebagaimana adanya pada saat penelitian berlangsung. Melalui penelitian deskriptif, peneliti berusaha mendeskripsikan peristiwa dan kejadian secara komprehensif.

\section{PEMBAHASAN}

\section{Tinjauan Pustaka}

\section{Pengertian Diskresi}

Pengertian discretion (Inggris) secara bahasa: freedom or authority to make dicisions and choises power to judge or act. Alvina Treut Burrows (ed) menyatakan discreation: ability to choose wisely or to jugde one self (kemampuan untuk memilih secara bijaksana atau mempertimbangkan bagi diri sendiri). Prajudi Atmosoedirdjo menerjemahkan discreation sebagai kebebasan bertindak atau mengambil keputusan menurut pendapat sendiri.

Adapun secara istilah, berikut ini penulis kutipkan beberapa pendapat:

Yan Pramadya Puspa dalam Kamus Hukum, menyatakan discretionair (Bel) berarti kebijaksanaan; memutuskan sesuatu tidak berdasarkan ketentuanketentuan peraturan, undang-undang atau hukum yang berlaku tetapi atas dasar kebijaksanaan, pertimbangan atau keadilan (Yan Pramadya Puspa, 2008: 230)

\section{Landasan Hukum Diskresi}

Esensi dari diskresi adalah kemerdekaan dan otoritas. Kemerdekaan sebegai esensi diskresi hukum adalah kemandirian dan keluasaan untuk melakukan tindakan yang tepat. Sedangkan otoritas adalah kewenangan mengambil pilihan dalam menetapkan hukum yang hendak diterapkan. Esensi diskresi yang demikian sesungguhnya sejalan dengan kedudukan dan kewenangan hakim sebagai pelaksana kekuasaan kehakiman. Karena dalam konstitusi dengan tegas dijelaskan, hakim adalah pelaksana kekuasaan kehakiman yang merdeka (contohnya pada pasal 24 UUD 1945 jo. Pasal 21 UU No. 4 tahun 2004).

\section{Pengertian Ijtihad}

Secara bahasa, ijtihad diambil dari kata al-juhd yang berarti ai-tsaqah (tenaga, kuasa, dan daya) dan al-jahd yang berarti almasyaqqah (kesulitan dan kesukaran) sementara al-ijtihad dan attajahud berarti bazl al-wus'i wa al-mahjud (penumpahan segala kesempatan dan tenaga) Sedangkan dalam kamus Al-Munawwir, ijtihad berarti berusaha dengan sungguh-sungguh (Ahmad Warson Almunawar, 1984:238). Kata ini beserta seluruh variasinya menunjukkan pekerjaan yang dilakukan lebih dari biasa atau sulit dilaksanakan dan tidak disenangi (Muhammad Musa At-Taiwana, 1972:79). Dalam kitab alMustasyfaz, Imam al-Ghazali merumuskan pengertian ijtihad menurut bahasa sebagai pencurahan segala daya upaya dan penumpahan segala kekuatan untuk menghasilkan sesuatu yang berat dan sulit (Muhammad Ibnu Muhammad Al Gazali, tt :478). Dari pengertian yang demikian ini, Idbal, di waktu membicarakan gerak dalam struktur Islam nuengidentikkan ijtihad dengan mujjahadah.

Sedangkan pengertian ijtihad secara terminologi, ada beberapa ulama 
memberikan definisi. Pertama, menumt al-Ghazali, ijtihad adalah "mencurahkan kemampuan untuk mendapatkan ilmu tentang hukum syara' sampai merasa dirinya tidak mampu lagi mencari tambahan kemampuan itu. Kedua, menurut al-Syatibi, ijtihad adalah "mengerahkan kesungguhan dan mencurahkan kemampuan untuk mendapatkan pengetahuan yang pasti dan zanni tentang hukum syara' (Abu Ishaq al-Syatibi, tt: 64). Ketiga menurut Imam al-Syaukani, ijtihad adalah "mencurahkan kemampuan untuk mendapatkan, hukum-hukum syara' yang bersifat operasional dengan jalan istinbath (menetapkan keputusan hukum) (Muhammad Ibnu Ali alSyaukani, tth.: 250).

\section{Hukum Beracara Peradilan Agama}

Hukum Acara Peradilan Agama adalah peraturan hukum yang mengatur bagaimana cara menaatinya hukum perdata materil dengan peraturan hakim atau cara bagaimana bertindak di pengadilan Agama dan bagaimana cara hakim bertindak agar hukum itu berjalan sebagaimana mestinya.

Peradilan Agama adalah Peradilan Perdata dan Peradilan Islam di Indonesia, jadi ia harus mengindahkan peraturan perundang-undangan negara dan syariat Islam sekaligus. Oleh karena itu rumusan Hukum Acara Peradilan Agama diusulkan sebagai berikut: "segala peraturan baik yang bersumber dari peraturan perundang-undangan negara maupun dari syariat Islam yang mengatur bagaimana cara orang bertindak di pengadilan Agama dan juga mengatur bagiamana cara Peradilan Agama tersebut menyelesaikan perkaranya, untuk mewujudkan hukum material Islam yang menjadi kekuasaan Peradilan Agama" (Blogspot, 2009: html).

Beracara di muka sidang pengadilan adalah suatu tindakan dalam melaksanakan rangkaian aturan-aturan yang termuat dalam hukum acara perdata. Hukum acara perdata adalah rangkaian peraturan-peraturan yang memuat cara bagaimana orang harus bertindak terhadap dan di muka pengadilan dan cara bagaimana pengadilan itu harus bertindak, satu sama lain untuk melaksanakan berjalannya peraturan-peraturan hukum perdata.

Dengan demikian penulis berpendapat, bahwa hukum acara perdata bertujuan untuk menjamin ditaatinya hukum perdata materil. Dengan demikian hukum acara perdata pada umumnya tidaklah membebani hak dan kewajiban seperti yang termuat dalam hukum perdata meteril, tapi memuat aturan tentang cara melaksanakan dan mempertahankan atau menegakkan kaidah-kaidah yang termuat dalam hukum perdata materil, atau dengan perkataan lain untuk melindungi hak perseorangan.

\section{Dasar Hukum Beracara di Pengadilan Agama}

Pada mulanya, Pemerintah Hindia Belanda tidak mempunyai peraturan khusus tentang Hukum Acara yang diperuntukkan kepada Rakyat Bumi Putra yang berperkara di Pengadilan. Tetapi karena kebutuhan yang sangat mendesak, Pemerintah Hindia Belanda mempergunakan Stb. 1819 No. 20 dengan sedikit 
penambahan dan perubahan yang tidak begitu berarti.

Adapun sumber hukum acara yang berlaku di lingkungan Peradilan Umum diberlakukan juga untuk lingkungan Peradilan Agama adalah sebagai berikut:
a. Reglement op de Burgelijk
Rechtsvordering (B.Rv)
b. Inlandsh Reglement (IR)
c. Rechtsreglement Voor De Buitengewesten (R.Bg)
d. Burgelijk Wetboek Voor Indonesia (BW)
e. Wetboek van Koophandel (WvK)
f. Peraturan Perundang-undangan
g. Yurisprudensi
h. Surat Edaran Mahkamah Agung RI
i. Doktrin atau Ilmu Pengetahuan (A.Basiq Djalil, 2006:153-157)

\section{Asas-Asas Peradilan Agama}

Asas Peradilan Agama adalah pedoman umum bagi Peradilan Agama dalam melaksanakan penerapan seluruh jiwa dan semangat Undang-Undang. Ada beberapa asas peradilan Agama yaitu:
a. Asas Personaliti Keislaman
b. Asas kebebasan
c. Asas wajib mendamaikan
d. Asas sederhana, cepat, biaya ringan
e. Asas persidangan terbuka untuk umum
f. Asas legalitas
g. Asas Equality
h. Asas aktif memberikan bantuan

\section{Kewenangan Peradilan Agama}

a. Kekuasaan Peradilan Agama

Berbicara tentang kekuasaan peradilan agama dalam kaitannya dengan Hukum Acara Perdata, biasanya menyangkut dua hal yaitu tentang "Kekuasan Relatif" dan "Kekuasaan Absolut", sekaligus dibicarakan pula di dalamnya tentang tempat mengajukan gugatan/permohonan serta jenis perkara yang menjadi kekuasaan Pengadilan.

\section{1) Kekuasaan Relatif}

Kekuasaan relatif diartikan sebagai kekuasaan pengadilan yang satu jenis dan suatu tingkatan, dalam perbedaannya dengan kekuasaan Pengadilan yang sama jenis dan sama tingkatan lainnya dalam hal wilayah mengadili. Pasal 4 ayat (1) Undang-undangan No. 7 Tahun 1989 yang berbunyi: “Pengadilan Agama berkedudukan di Kota Madya atau Kota Kabupaten, dan daerah hukumnya meliputi wilayah Kota Madya atau Kabupaten. (Roihan A. Rasyid, t.th.: 26)

Dari Undang-Undang di atas dapat dijelaskan, pada dasarnya tempat kedudukan Pengadilan Agama ada di Kota Madya atau Ibu Kota Kabupaten, yang daerah hukumnya meliputi wilayah Kota Madya atau Kabupaten, tetapi tidak tertutup kemungkinan adanya pengecualian.

$$
\text { Jadi tiap-tiap Pengadilan }
$$
Agama mempunyai wilayah tertentu atau dikatakan mempunyai yurisdiksi relatif tentang dalam hal ini meliputi satu Kota Madya atau satu Kabupaten, atau dalam keadaan tertentu sebagai pengecualian.

Yurisdiksi relatif ini mempunyai arti penting 
mengajukan hukum dispensasi nikah. Untuk itu, dengan kemerdekaan dan otoritas yang dimilikinya, hakim harus menemukan alasan hukum melalui menafsirkan, pemaknaan sehingga dirumuskan alasan hukum dispensasi nikah.

Berdasarkan pada penafsiran pada umumnya hakim merumuskan alasan dispensasi antara lain adanya kemudharatan bila tidak dilakukan pernikahan meskipun calon mempelai belum mencapai usia minimum. Karena menurut hukum Islam, menolak kemudharatan harus didahulukan dari pada meraih manfaat (dar'ul mafasid muqadamun ala jalbilma). Berbeda dengan penegak hukum lainnya, seperti polisi dan jaksa, faktor yang melatar belakangi diskresi hakim tidaklah banyak. Hanya ada dua faktor yang melatarbelakangi diskresi hakim, yaitu faktor legal dan factor professional individual.

\section{Faktor Legal}

Faktor legal yang melatarbelakangi diskresi hakim merupakan faktor yang berkaitan dengan Peraturan PerundangUndangan. Diskresi hakim dilatarbelakangi oleh Peraturan Perundang-Undangan yang ada. Karena berangkat dari PerundangUndangan itulah diskresi hakim dinilai shalih.

\section{Faktor Professional Individual}

Undang-undang merupakan produk (politik) dari lembaga legislatif, akan tetapi hakim yang akan menerapkannya terhadap kasus yang bersifat individual. Dalam prakteknya, aturan hukum dalam Undang-Undang (hukum inabstracto) tidak selalu sama persis dengan peristiwa yang membutuhkan penegekan hukum.
Diskresi hukum yang dilakukan oleh hakim, kemudian diperlukan keahlian profesi agar dapat mencapai tujuannya, untuk menegakkan hukum dan keadilan. Berdasarkan kenyataan objektif tersebut, penerapan Undang-Undang sebagai hukum in concreto, kemerdekaan dan otoritas hakim untuk dapat melakukan penafsiran dan penerapan hukum dengan bijaksana memerlukan pengetahun dan keahlian profesional. Dengan kata lain, diskresi ternyata memerlukan keahlian profesional. Ini berarti latar belakang dan pengalaman intelektual sangat berpengaruh ketika hakim melakukan diskresi hukum. Urgensi latar belakang profesional individual hakim untuk melakukan diskresi, tampak dalam kaitannya dengan ketentuan syarat menjadi hakim. Secara umum syarat menjadi hakim adalah individu yang well studied dan well moralized. Dengan well studied pendidikan yang baik,

\section{Landasan Hakim dalam Menetapkan Diskresi Hukum di Pengadilan Agama}

Pelaksanaan putusan dengan sukarela ialah terwujudnya realisasi amar putusan itu oleh pihak yang kalah tanpa melalui pemaksaan oleh pengadilan. Jadi pihak-pihak yang menang menunggu kemauan dari pihak yang kalah sebagai pihak yang dihukum untuk melaksanakan prestasi, apakah ia mau melaksanakan tanpa melalui pertolongan pengadilan atau ia tidak mengindahkannya. Kalau pihak yang kalah telah melaksanakannya, maka selesailah urusan pelaksanaan putusannya, inilah kondisi yang ideal dalam pelaksanaan putusan Hakim. Sekiranya pihak yang kalah mengabaikan kewajibannya membayar prestasi dalam putusan pengadilan, pihak yang menang 
dapat mengingatkan kepada pihak yang kalah melalui permohonannya kepada pengadilan dan pengadilan memberikan teguran (aan maning) kepada pihak yang kalah untuk melaksanakan putusan tersebut. Jika pihak yang kalah bersedia melaksanakan amar putusan tersebut, maka putusan telah dilaksanakan dengan sukarela. Tetapi setelah dilakukan teguran oleh Pengadilan, pihak yang kalah tidak mengindahkan, maka putusan yang telah berkekuatan hukum yang tetap itu tidak dapat dijalankan dengan sukarela oleh pihak yang kalah, selanjutnya Pengadilan dapat melaksanakan proses eksekusi (pelaksanaan putusan dengan upaya paksa) melalui Pengadilan tersebut sebagaimana telah diatur dalam Rbg pasal 207 dan 208jo HIR pasal 196 dan 197 (Yahya Harahab, 1995: 5).

Berdasarkan data di Pengadilan Agama Batusangkar Kelas IB, (Wawancara, Dra. H. Admiyarti, 2013). Pengadilan Agama Batusangkar Kelas IB telah banyak menyelesaikan sengketa harta bersama baik gugatan rekonpensi maupun sengketa harta bersama, pihak pengadilan menyerahkan sepenuhnya pembagian harta bersama tersebut kepada pihak yang berperkara, hal ini dilakukan mengingat tidak adanya kewenangan pengadilan untuk ikut campur dalam pembagian harta bersama tersebut karena para pihak telah bersedia menyelesaikannya secara sukarela.

Manfaat dari putusan yang dilaksanakan secara sukarela dirasakan oleh pihak pemohon eksekusi. Dangan adanya pelaksanaan putusan secara sukarela, pemohon eksekusi tidak perlu mengeluarkan dana untuk pelaksanaan putusan tersebut dan terhindar dari kerugian moral pada sisi lain. Pelaksanaan putusan secara eksekusi baru dapat dijalankan apabila putusan pengadilan telah memperoleh kekuatan hukum tetap. Ini merupakan asas pokok kecuali dalam putusan yang dapat dijalankan lebih dulu atau dalam putusan provinsi. Oleh karena itu, tanpa mengabaikan pengecualian dimaksud, pada dasarnya eksekusi dapat dijalankan apabila putusan tersebut tidak mungkin lagi diajukan upaya banding atau kasasi.

Salah satu alternatif agar pelaksanaan eksekusi dapat dilaksanakan adalah dengan melaksanakan eksekusi prodeo (Wawancara, Dra. Hasnayeti, M,MA, 2013). Agar pelaksanaan eksekusi secara prodeo tidak bertentangan dengan hukum, maka tidak disebut eksekusi secara prodeo, tetapi memprodeokan pemohon eksekusi dari kewajiban mendahulukan pembayaran biaya eksekusi. Dengan mempergunakan istilah "memprodeokan pemohon eksekusi dari kewajiban mendahulukan pembayaran biaya eksekusi", pada eksekusi itu masih "tetap melekat" biaya eksekusi. Oleh karena biaya eksekusi tetap melekat pada eksekusi, biaya eksekusi yang didahulukan pembayarannya oleh Pengadilan Agama tetap bisa ditagih pengembaliannya dari pihak tergugat.

Penerapan yang seperti ini perlu dipikirkan dalam menghadapi kemacetan eksekusi yang disebabkan pemohon tidak mampu membayar lebih dulu biaya eksekusi. Membayar biaya perkara saja berat, apalagi panjar biaya eksekusi, yang dapat dianggap, merupakan suatu kewajiban hukum, yang tidak mampu dipikul oleh Pemohon Eksekusi yang miskin, sedangkan harta satu-satunya 
yang dimilikinya hanya harta benda yang telah dikuasai oleh Tergugat. Untuk itu, eksekusi tidak mungkin dilakukan seandainya tidak dikabulkan secara prodeo.

Memberi dispensasi dengan cara mendahulukan pembayaran biaya eksekusi adalah hal yang pantas (Wawancara, Dra. Hasnayeti, MMA: 2013). Caranya dengan jalan mengajukan permohonan dengan mempergunakan penafsiran "analogis" Pasal 237 HIR atau Pasal 273 RBg, yakni pemohon eksekusi mengajukan permohonan dispensasi agar dibebaskan dari kewajiban mendahulukan pembayaran biaya eksekusi. Permohonan dilampiri dengan surat keterangan tidak mampu dari pejabat setempat yang berwenang untuk itu. Atas permohonan itu diadakan pemeriksaan insidentil oleh Majelis Hakim untuk menentukan apakah permohonan tersebut cukup beralasan.

Kendala yang dihadapi oleh pengadilan adalah karena perkara eksekusi prodeo merupakan sesuatu yang baru di pengadilan, maka pelaksanaanya masih belum maksimal baik secara lapangan maupun secara administrasi. Mahkamah Agung sebagai atasan pengadilan tidak memfokuskan pelaksanaan bantuan hukum tersebut kepada biaya eksekusi prodeo karena minimnya pelaksanaan eksekusi di lingkungan Pengadilan Agama. Mahkamah Agung lebih memfokuskan kepada pelaksanaan biaya perkara prodeo biasa dan pelaksanaan sidang keliling. Terutama untuk lingkungan Pengadilan Agama Batusangkar, Mahkamah Agung tidak menganggarkan dana eksekusi prodeo, tetapi lebih mengutamakan biaya prodeo untuk pelaksanaan perkara biasa dan pelaksanaan sidang keliling. Hal ini disebabkan karena jarang perkara di Pengadilan Agama Batusangkar yang sampai kepada tahap eksekusi dan masyarakat di Kabupaten Tanah Datar lebih membutuhkan dalam perkara prodeo biasa dan sidang keliling di mana Kabupaten Tanah Datar terdapat wilayahwilayah yang jauh dan sangat sulit untuk dikunjungi sehingga menyebabkan kesulitan para pencari keadilan dalam berurusan ke Pengadilan.

Hukum memiliki sistem keadilan, yang tanpa memandang dan tanpa membeda-bedakan. Setiap orang memiliki kedudukan yang sama di mata hukum, maka oleh sebab itu setiap orang yang merasa dirugikan, merasa disakiti, dianiaya berhak memiliki perlindungan hukum. Tidak tertutup kemungkinan juga persoalan ini dikaitkan dalam kasus perkawinan. Jika dalam kasus cerai talak, suami diberikan beban untuk membayarkan nafkah iddah yang akan dijalani oleh istri didasarkan suami yang menginginkan perceraian tersebut, maka sepantasnya jika istri yang berstatus sebagai penggugat yang dalam hal ini dia yang mengingikan perceraian juga diberikan hak untuk memperoleh hak iddah tersebut. Manakala keinginannya mengajukan gugatan perceraian didasarkan atas kekejaman yang telah dilakukan oleh bekas suaminya, maka pantaslah majelis hakim membebani bekas suami untuk memberikan nafkah iddah untuk istrinya. Dalam undangundang perkawinan dan peraturan pelaksanaannya tahun 1974 Pasal 41 huruf c menyebutkan Pengadilan dapat mewajibkan kepada bekas suami untuk memberikan biaya penghidupan dan menentukan suatu kewajiban bagi bekas istri. 


\section{PENUTUP}

Hakim menetapkan diskresi hukumnya dengan beberapa alasan dimulai dengan menemukan fakta dan memilah faktor mana yang relevan sehingga hakim melakukan konstatir fakta dengan menggunakan analisis sylogisme fakta tersebut dengan premis mayor yang berupa Undang-Undang dan premis minor berupa alasan-alasan yang diajukan oleh para pihak kemudian baru dilakukan ijtihad yang berbentuk putusan hingga menjadi sebuah kekuatan hukum.

Hakim dalam melakukan diskresi hukum mempunyai alasan yuridis seperti Pasal 24 Undang-Undang Dasar 1945, Undang-Undang Nomor 28 tahun 2004 dan pasal 132 HIR /148 RBg. Dengan ada aturan ini secara otomatis memberikan kebebasan kepada hakim untuk menggali nilai keadilan yang hidup dalam masyarakat. Kemudian Undang-Undang Nomor 1 tahun 1974, Kompilasi Hukum Islam (KHI) pada prinsipnya Hukum Islam menolak kemudaratan harus didahulukan dari pada meraih manfaat (dar'ul mafasid muqadamun ala jalbil mashalih). Kewenangan hakim dalam menentukan dan mentapkan sebuah putusan berlandasan kepada aturan yang berlaku apabila tidak ditemukan, maka sebagai alternatif untuk mengisi kekurangan dan kelemahan dalam penerapan azaz legalitas seorang hakim harus memahami hukum dalam konteks yang tepat dan bertindak sebagai a creative lawyer.

\section{DAFTAR KEPUSTAKAAN}

Abdullah, Abdul Gani,. 1991. Himpunan Perundang-undangan dan peraturan Pegadilan Agama. Jakarta: PT Inter Masa.

Abdurrrahman. 2008. Kompilasi Hukum Islam di Indonesia. Jakarta: Akamedia Presindo.

Azizy, Ahmad Qodri. 2006. Menggas Ilmu Hukum Indonesia, dalam Gunawan, Ahmad dan Mu'ammar Ramadhan, ed, Menggagas Hukum Progresif Indonesia. Yogyakarta: Kerjasama Pustaka pelajar, IAIN Walisongo dan Pragram Doktor Ilmu Hukum UNDIP.

Contohskripsitesis, Kewenangan Diskresi Kepolisian dan Pertanggungjawabannya secaraHukum www.contohskripsitesis.com

Erlyn, Indarti. 2002. Diskresi Polisi. Semarang: Badan Penerbit Undip.

Gifs, Steven H. 1975. Law Dictionary. New York: Barron's Educational Series, I.

Manan, Bagir. 2001. Hukum Positif Indonesia (Satu Kajian Teoritik). Yogyakarta: FH UUI Press.

Zoebir, Zuryawanis Vandiar, Penyalahgunaan Diskresi pada Kebijakan Mobil Nasional, zuryawanisvandiarzoebir.blogspot. com

Puspa, Yan Pramadya. 2004. Kamus Hukum. Semarang: Aneka Ilmu.

Soekanto, Soerjono. 2006. Pokok-Pokok Sosiologi Hukum. Jakarta: PT RajaGrafindo Persada.

Syarifuddin, Amir. 2001. Ushul Fiqh Jilid 2. Jakarta: Logos Wacana Ilmu. 
Utsman, Sabian. 2008. Menuju Penegakan Hukum Resposif. Yogyakarta: t.p.

Sabiq, Sayid. T.th. Fiqih SunnahII: Bairut: Daar al Fikr.
Wingjosubroto, Soetandiyo. 1981. Pengolahan dan analisa data dimuat dalam Koentjoraningrat, Metodemetode Penelitian Masyarakat. Jakarta : Gramedia. 